\title{
Thymoma Type A
}

National Cancer Institute

\section{Source}

National Cancer Institute. Thymoma Type A. NCI Thesaurus. Code C6454.

A thymic epithelial neoplasm characterized by the presence of spindle and/or oval neoplastic epithelial cells. Lymphocytic infiltration is minimal or absent. It may be associated with myasthenia gravis or pure red cell aplasia. The majority of cases occur in the anterior mediastinum as Masaoka stage I tumors. Approximately $20 \%$ of the cases occur as stage II or stage III tumors. Type A thymoma generally behaves as a benign tumor and the overall survival is reported to be $100 \%$ at 5 and 10 years. 